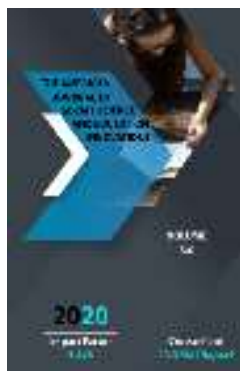

\section{The Theoretical And Practical Model Of Making A Person Socializing Economically}

\author{
Navbakhor Umarova \\ Doctor Of Philosophy Phd, Uzbek State University Of Physical Education And Sport Tashkent, \\ Uzbekistan
}

Journal Website: http://usajournalshub.c om/index,php/tajssei

Copyright: Original content from this work may be used under the terms of the creative commons attributes 4.0 licence.

\title{
ABSTRACT
}

The article is about theoretical and practical model of economic-socialization of preschool, primary and teenagers age classification.

\section{KEYWORDS}

Microsothia, preschool, primary age, teenagers age, economic socialization

\section{INTRODUCTION}

An in-depth analysis of the current state of our country requires that today the world market conditions have changed dramatically, and the growing competition in the conditions of globalization necessitates is a completely new approach and the development and implementation of the principles for a more stable and dynamic development of our state. As President Shavkat Mirziyoyev noted that “... in the current globalization period, where the deep financial and economic crisis continues in the world, in a steadily increasing competition, we thoroughly analyze the path of our country's progress, to develop our country at a steady and rapid pace, we have developed a strategy for action in five priority areas of development of the Republic of Uzbekistan for 2017-2021."'[1].Successful implementation of large-scale economic reforms and social transformations in our 
country depends, first of all, on the efficiency of economic and financial institutions. Therefore, they should not only produce strategic objectives for the short and long-term economic strength of the country, but also ensure their implementation. The problem which Bringing up economically the person in family and educational institutions who main hero of social and economic changes in our country and who responsible to implement them, that is, learning and investigating his/her economical socialization is one of the burning issues which waiting for its solution and should be solved by specialists of this field particularly social psychologists.

Naturally, the results and scales of implementing reformsdepends on the algorithm of correct and successive behavior in economical consciousness and economical manners of children who being brought in family. Logically, Child's setting to market relations appears in psychological processes, economical socialization and identified with the help of series factors.

Basing on "The strategy for actions on five priority areas of Development of the Republic of Uzbekistan in 2017-2021" in the same time with all opportunities are being created by government to develop family business, forming business motivations in youth under influence of family atmosphere, process of economical socialization and interpersonal relations in family is one of the burning issues.

\section{MATERIAL AND RESEARCH METHODS}

Logically, it is important to bring up ascending young generation in gaps in adolescence period appropriately changing conditions relying on exact knowledge. Therefore, one of the functions of specialists of the field is toabsorbthe idea about economicalevents, that is to form knowledge about incidents and occurrences which appear in economical world appropriately childhood stages, when the child is becoming person. An Efficiency in the first stage of socialization depends mainly on family, domestic social psychological surroundings and how well parents do their duty,particularly family socialization. In the next stages the role of educational institutions and labor groups becomes more and more significant appropriately that new field's socialization - "economical socialization" demands assimilating.

\section{RESULTS AND DISCUSSION}

Learning impacts of social-psychological factors to process of economical socialization of pre-school age, schoolchildren, adolescents and teenagerswho chosen as an object of our researches, investigate their activity, their position to significant situations, events, objects which belongs to themselves and messages as well as attitude to motivation andin this finding out the role of connective psychological mechanism subjective reality with objectivity are implemented using "The Conception of social imagination" which recommended by S. Moscowichi [3], J.Jodelet [4], A.I. Donsov and T.P.Yemelyanova [5], M.K. Blok [6], M.I. Volovikov[7]. In finding out that children's imagination on money is important circumstance it is also useful that B.M Karimova's [8] “Three measured modelReason: "Social imaginations are such changeable dynamic structures during the life, their formation and modification mechanisms are also important inowner of imagination how percepts social universe, processes of sticking in knowledge system of objects which acquired personal meaning, appearing in behavior, becoming personal experience" [8]. Because of that, this model enables us to measure level 
of subject of imaginations' information about member who owns a certain "sociometricposition" in a family, mark and description for this, as well as settings for money, which appears directly in behavior.

Additional methodological base for our scientific researches is "The idea of culturalhistorical approach" of L.S.Vigotskiy[9] which aimed at interpretation that social events,according to this idea, all characteristic sensesis digestingactively either relations and events by individ in society. But, individ does not only receives experience and cultural progresses which created by humanity, but also digests estimating with own reserves and even innate specifics. Such digesting does not require slavish imitation, but digests internal activity.For instance, the example of behavior of person, which forms under the impacts of micro-factors [10] and the mutual proportion of marketing (market relations) which created by members of society as well as such basing process of harmonization [11] enable us to find out the degree of economical socialization.

The central issue of our this researches - the process of economical socialization of person is displayed as the result of digesting to modern and traditional costumes in society which based on its market relation. This is economic socializationthe social character of the process, understanding the identity of a person, the complexity of biological and social factors in human nature.

The impact of the factor of group relations which forms as "Mean $\rightarrow$ money $\rightarrow$ purpose" and "reason $\rightarrow$ money $\rightarrow$ result" to the process economical socialization of person as well as social-psychological features of system "social settings $\rightarrow$ the laws of life $\rightarrow$ attitude to money" are observed by point "The Conception of self-realizing" recommended by V.S. Mukhina [12] and "dispositional theory" of V.A.Yadov [13],[14].On the basis of this theory and conception, the idea of socially significant values is being acquired by human beings through existing human norms and philosophies in the human ontogenesis, and the realization of these values through selfrealization.

As well as "The theories of approximation to the person actively" of Russian psychologists which"activity $\rightarrow$ mind $\rightarrow$ person"(A.N.Leontev) [15], “internal↔externalactivity”(S.L.Rubinstei n) [16] "social environment and activity"(A.V.Petrovski) [17], "self-regulation and behavior"(V.A. Yadov) [14], "person and social relations" (G.M.Adreyeva and V.N. Myasishev) [18],[19], "necessity and social gratification"(K.K.Platonov, V.S. Magun, M.Y. Semenov and Y.G.Yefremov) [20],[21],[22], "activity and development of person"

(K.A. Abulhanova-Slavskaya) [23],[24] can be methodological base.

The practical and theoretical model of economical socialization to person, which includes four stages of the life which chosen properly the program of our scientific researches is convenient four us to explain that structure "sensibility to economical events $\rightarrow$ dominant environment which affects to the process of person's economical socialization $\rightarrow$ effective result" of the subject of economic relations the sensibility of preschool child to surrounding economical events in the process of economical socialization in expressed byhesitating in sending money and mainly explained by appearance of regretting for money. In this case,the most dominant social atmosphere which affects to process is the atmosphere of his/herfamily. As well as, period of this age isalso called as "the stage of formation economical intelligence", and explained with the effective result in successfully economical socialized child which; 
(a) formation the sense of self-regulation respecting; (b) ability to direct his/her actions to economic relations; (c) knowing aims exactly consumer.

The next developing stage of economical socialization in the model is suitable for elementary school age. In spite of that sensibility to events appears when child demonstrates voluntary internal aspiration for working in economic relations complying the willing of parentsend delimiting own independence,this process is money's dignity, the most dominant social atmosphere which effects to success/failure of the process is referent group (it maybe family on educational institutions. In addition, in particular, this stage is called as "the stage of formation economical empathy and consciousness". The effective end of the marked with level of: (a) formation of qualification and skills to spend money; (b) increase of trust in the actions of the adult family due to an understanding of the economic situation; (c) ability to show ability as a consumer.

The third stage of theoretical and practical model includes period of teenager of person's developing. It can be marked that sensibility to economical events by researching worrying about others and submitting to them, ability to defend own property, understanding that his or her family's prosperity depends on economics of the country of the person very tightly wherewith the economical-social roles of teenager in economic relations. In contrast to age periods above, in this stage the most dominant effective atmosphere is which the person's coevalsactives. Basing on our practical and theoretical researches, we call this development period as "The stage of formation economical guarding".

A teenage / youth-oriented adult is: (a) who develops his / her identification feels personal "Me"; (b) an independent opinion; (c) the ability to evaluate economic value based on the value of commodities; (g) show that he / she has shown a strong will to others around the world and consequently has beensucces sful/unsuccess fulin the economic process.

The final stage of the model we represent is theage-related development of the adolescent. Adolescents, who are the subject of economic socialization, show their sensitivity to events by understanding the fact that by age, they have the ability to perceive socio-economic events occurring around them, to communicate their own personal relationships, and to understand what can happen in the interest of conflict. At this, microsothia being an impressive environment, which, in turn, indicates that gradually the workforce in the person's life is gradually gaining value. We call this stage as "formation of economic responsibility". The high level of optimism is, in turn, influential in the process of economic socialization, and the result of effective economic societies is: (a) feeling responsible for the peace of the country and the development of the country; (b) feeling small and family-friendly and contributing to the wellbeing and prosperity of their own family; (c) to know that natural resources and the environment have a character of preservation, diligence and generosity; (g) the full understanding of socio-economic issues and the ability to acquire the necessary decisions to resolve them.

Thus, the proposed model is far from the amorphous nature of the proposed model, and according to the future research plan, it is also possible to create an 


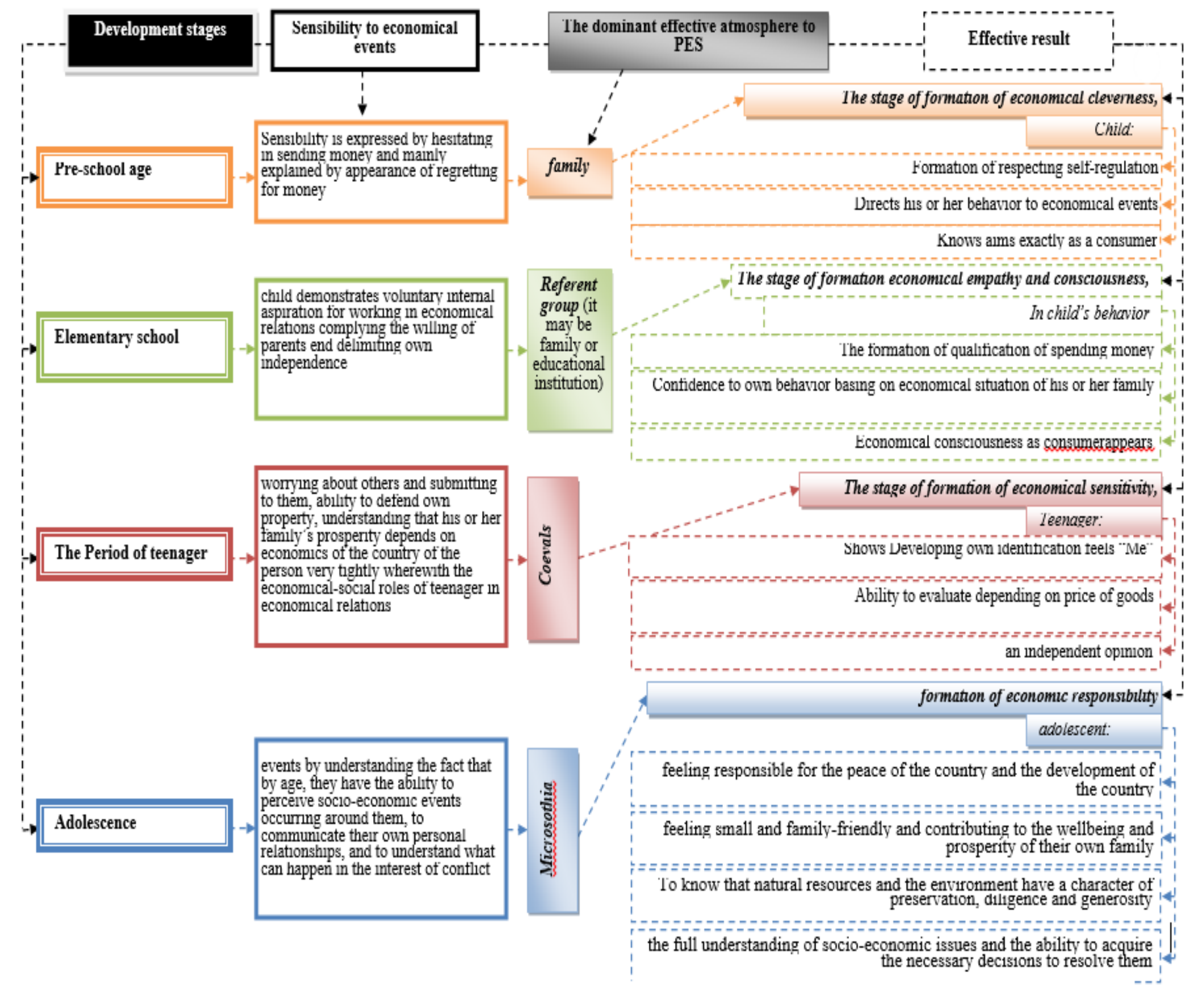

\section{1-Graph.The theoretical and practical model of economical socialization to person}


invariant model that includes the subsequent stages of continuous education.

\section{CONCLUSIONS}

In general, E.G.Gaziev [25] classification based on individual socialization's theoretical and practical economic model, based on their socio-psychological analysis, asserts as we offer the following advice:

1. Ensuring the successful economic socialization of preschool children preschool education teacher in collaboration with the family members of children: (a) the initial conception of the national currency, (b) to satisfy the demand for the material needs of the parents to follow the advice of such qualities; (a) directing their actions towards economic relationships, (b) setting up practical skills that will help them develop their skills as a consumer.

2. Presentation of "Photographs of banknotes" at the work of pupils of small school age as a diagnostic tool of practical psychologists in the organization of practical work aimed at increasing the role of "family-child-pedagogical" in the individual's economic socialization, the proactive method "If I am a magician"; "The role of money in our lives" work with teens, A. Furnham and M. Argyle "Determination of the person's money stamps", "Methodology for assessing the economic status of a subject"; In working with adolescents, A.A. Kapustin and M.Yu. Semenov's "Uncompleted Sentences", M.R. Rokich's "Values Orientation" methodology, P.N. Ivanov, E.F. From the methodology of Kolobovs "Determination of vital values of a person (Must-test)" and It is desirable to use socio-psychological surveys by V.M. Karimova, N.Sh. Umarova.

3. It is appropriate to use the psychological mechanisms of the market economy and its formation in gradual transferring the person to economic relations in preschool, general secondary, secondary special, vocational and higher education institutions. Indeed, strengthening "the family-child-pedagogical" cooperation is of great practical significance for the proper and effective economic socialization of the individual.

4. In the general education school pupils, in collaboration with the School Psychologist, a teacher of economic sciences in the implementation of social projects aimed at the development of economic well-being, attitudes and entrepreneurial skills, and in developing their economic mindset, thinking and thinking: "Teenagers and market economy", "Economic socialization of adolescents in the context of family and educational institutions" it is of particular importance that the roundtable discussions are organized.

\section{SOURCES}

1. The decree of the President of the Republic of Uzbekistan about "On the forecast of the main macroeconomic indicators and parameters of the state budget of the republic of uzbekistan for 2019 and budget 
focuses for 2020-2021" PP-4086 of december 26, 2018.

2. The Message from the President of the Republic of Uzbekistan Shavkat Mirziyoyev to the Oliy Majlis on December 28, 2018.

\section{REFERENCES}

3. Moscovisi S. Sur les representations jociles. - P., 1979. - P. 632.

4. Jodelet J. Reresentetion sociali; phenomenes, concert et theorei // Moscovici S. (ed) psychologie socialr. - P.: 1984. - P. 360.

5. Altman M. Ed. Handbook of Contemporary Behavioral Economics // M.E. Sharpe. - NY.: Armonk, 2006. - $624 \mathrm{p}$

6. Danziger K. Children's Earliest Conceptions of Economic Relations / K.Danziger // J. of Social Psychology. - 1958. - N 47. - P. 231240.

7. Eiser J.R. Social Psychology: Attitudes, cognition and social behaviour. Cambridge: Cambridge University Press, 1986. - 188 p.

8. Furnham A., Argyle M. The Psychology of Money. - London and New York, Routledge, 1998. - $482 \mathrm{p}$.

9. Furnham A., Lewis A. The Economic Mind: The social psychology of economic behaviour. - Brighton: Wheatsheaf, 1986. $246 \mathrm{p}$.

10. Gibb A. Stimulating Entrepreneurship and New Business Development / A. Gibb. Geneva: International Labor Office, 2000. P. 35 . 